\title{
Characterization of munguba oil obtained by ultrasound
}

\author{
Aléxia Lorenzi Raiser ${ }^{1}$ Maycon de Paula Ribeiro Torres ${ }^{2}$ (i) Elton Brito Ribeiro ${ }^{2}$ (B) \\ Dênia Mendes de Sousa Valladão ${ }^{2 *}$ (D)
}

${ }^{1}$ Programa de Pós-graduação em Ciências Ambientais, Universidade Federal de Mato Grosso (UFMT), Sinop, MT, Brasil. ${ }^{2}$ Universidade Federal de Mato Grosso (UFMT), 78550-728, Sinop, MT, Brasil. E-mail: deniavalladao@gmail.com. "Corresponding author.

ABSTRACT: This study analyzed the use of the ultrasound-assisted method as an alternative to obtain munguba oil. The extraction provided a $47.70 \%$ yield of an oil with appropriate quality, evaluated by assessing the \%FFA as oleic acid, iodine, peroxide, and saponification values, in addition to the refractive index and density. The oil presented thermal stability up to $300{ }^{\circ} \mathrm{C}$, was constituted mainly by palmitic acid (C16:0), and presented a total phenolic content of $55.02 \pm 1.872 \mu \mathrm{gEAG} \mathrm{g}^{-1}$. Results suggest that the ultrasound-assisted method has the potential to obtain vegetable oils without compromising their characteristics and quality, as well as optimize extraction time, solvent volume, and operational costs. Moreover, munguba oil presents itself as a suitable and sustainable alternative as an adjuvant in food products, pharmaceuticals, cosmetics, and biofuels.

Key words: extraction, Pachira aquatica Aublet, ultrasound, vegetable oil.

\section{Caracterização do óleo de munguba obtido por ultrassom}

RESUMO: $O$ estudo analisou a aplicação do método de extração assistida por ultrassom como método alternativo para a obtenção do óleo de munguba. A extração do óleo resultou num rendimento de $47.70 \%$ com qualidade adequada avaliada pela \%AGL como indices de ácido oleico, iodo, refração, peróxido, saponificação e densidade. O óleo apresentou estabilidade térmica até $300{ }^{\circ} \mathrm{C}$ sendo constituido majoritariamente do ácido palmítico (C16:0) e expressou um teor de fenóis totais de $55.02 \pm 1.872 \mu \mathrm{g} / \mathrm{EAGg} \mathrm{G}^{-1}$. Os resultados sugerem que o método de extração assistida por ultrassom apresenta potencial para obtenção de óleos vegetais sem alterar suas características e qualidade, além de possibilitar a otimização do tempo, volume de solvente e custo operacional. Ainda, o óleo de munguba mostra-se como alternativa sustentável na aplicação como adjuvante em alimentos, medicamentos, cosméticos e biocombustiveis.

Palavras-chave: extração, Pachira aquatica Aublet, ultrassom, óleo vegetal.

\section{INTRODUCTION}

Munguba (Pachira aquatica Aublet (Malvaceae)) (THE PLANT LIST, 2019) is a fruitful species that can be found from southern Mexico to northern Brazil (DOURADO et al., 2015). The fruits are similar to the ones from the cocoa tree (Theobroma cacao L) and have high amounts of lipids, proteins, and carbohydrates (LORENÇON et al., 2016). They can be consumed raw, roasted, cooked or toasted (JORGE \& LUZIA, 2012). Inside the fruit, there are several seeds containing high amounts of oil constituted mainly by palmitic and oleic acids (SILVA et al., 2015; RODRIGUES et al., 2019).

Vegetable oils have been studied as alternative sources in the development of biofuel and cosmetic, pharmaceutical, and food products (JORGE \& LUZIA, 2012; LORENÇON et al., 2016; OLIVEIRA et al., 2019). The quality of these oils and their bioactive compounds depend on several factors, such as raw materials origin, storage conditions, utilized extraction solvent, and, especially, the extraction process applied (PEREIRA et al., 2017).

Alternative oil extraction methods that minimize time, solvent volume and oil degradation have been studied in order to optimize traditional methods, such as maceration, percolation and Soxhlet extraction (HELENO et al., 2016; HERNÁNDEZSANTOS et al., 2016; MARAN et al., 2017). Ultrasonic assisted extraction uses the energy of ultrasonic waves, which cause cavitation processes and lead to high shear forces that cause flaking, 
erosion, and breakage of the particles. Furthermore, they promote the hydration and swelling of the particles, which increase pore size, the diffusion process of the solute and, consequently, mass transfer (TIWARI, 2015; CHEMAT et al., 2017). This method is highly efficient and consumes little energy, making it a viable alternative to traditional methods. It can be successfully adopted in the processing of vegetable samples, besides its sustainable aspects (HERNÁNDEZ-SANTOS et al., 2016). The method also presents other advantages such as low cost and simple technique and equipment requirements (PERRIER et al., 2017).

Therefore, this paper aims to evaluate the quality and the fatty acid profile of the oil obtained from the munguba seeds, extracted by the ultrasoundassisted method.

\section{MATERIALS AND METHODS}

\section{Harvesting spot}

The munguba fruits were collected at the Parque Florestal in Sinop, Mato Grosso (S11 50 '06,20"; W55 30'02,30"), and taken to the quality control laboratory at Federal University of Mato Grosso, Campus of Sinop. The botanical identification was performed at Mato Grosso North-central herbarium (CNMT) located at the Sinop Campus of the Federal University of Mato Grosso. Its exsiccate was stored under the registration number 4506 .

\section{Fruits preparation for extraction}

The munguba fruits were dried in a forced convection oven at a temperature of $40 \pm 2{ }^{\circ} \mathrm{C}$ for 48 -72 hours. This caused the fruits to open, exposing their seeds, and reduced their moisture $(<10 \%)$. The seeds were then ground using a ball mill.

\section{Oil extraction}

The ultrasound-assisted extraction was performed according to RAISER et al., (2018b) using hexane as the extraction solvent. The milled seeds were put in a 1000 milliliters bottle along with the extraction solvent in the ratio of 1:5 (weight/volume $[\mathrm{w} / \mathrm{v}])$. This mixture was submitted to an ultrasonic bath (Cristófoli ${ }^{\circledR}$ ) for 2 hours at a frequency of 45 $\mathrm{kHz}$ and a temperature of $35 \pm 2{ }^{\circ} \mathrm{C}$. After that, the extraction liquid was vacuum filtered then evaporated in a rotary evaporator at a temperature of $50 \pm 2{ }^{\circ} \mathrm{C}$, providing the oil which was stored at a temperature of $5 \pm 2{ }^{\circ} \mathrm{C}$.

The sample was also extracted using a Soxhlet apparatus according to RODRIGUES et al.,
(2019), with some modifications. The sample was packed into the extraction chamber of the Soxhlet extractor; while the solvent hexane was poured into the round bottom flask of the extractor. The whole set-up was assembled on a heating mantle at $60{ }^{\circ} \mathrm{C}$ and allowed to reflux for 2 hours. The extract was evaporated using a rotary evaporator at a temperature of $50 \pm 2{ }^{\circ} \mathrm{C}$.

\section{Oil physicochemical characterization}

The following tests were performed according to AOCS (2004): \%FFA ( $\%$ of free fatty acids) as oleic acid ( $\mathrm{Ca} 5 \mathrm{a}-40)$, iodine value ( $\mathrm{Cd} 1 \mathrm{~d}-$ 92), refractive index (Cc7-25), peroxide value $(\mathrm{Cd} 8 \mathrm{~b}$ -90), saponification value ( $\mathrm{Cd}-25)$, density (Cc 10a - 25) and melting point (capillary method) (Cc 3-25).

Viscosity was determined on a rotary viscometer (Myr - VR 3000). The sample was kept in a water bath and the viscosity values were measured according to the temperature variation, from $30^{\circ} \mathrm{C}$ to 60 ${ }^{\circ} \mathrm{C}$, using the $\mathrm{L} 2$ spindle and rotation speed of $200 \mathrm{rpm}$.

\section{Thermogravimetric analysis (TG-DTG curves)}

A thermogravimetric analyzer (Shimadzu TGA-50) was used to evaluate the oil's thermal stability, moisture, and ash content, providing TG-DTG curves. The samples were assessed in a nitrogen atmosphere, from 30 to $600{ }^{\circ} \mathrm{C}$, at a heating rate of $10{ }^{\circ} \mathrm{C} \mathrm{min}-1$, using an $\alpha$-alumina pan (PARDAUIL et al., 2017).

\section{Differential scanning calorimetry (DSC)}

The DSC curve was assessed with a differential scanning calorimeter (DSC 60 Plus/ TAC (Shimadzu)), by weighing approximately 1 $\mathrm{mg}$ of the sample into a sealed aluminum pan and then performing the analysis in a nitrogen rate flow of $50 \mathrm{~mL} / \mathrm{min}$ and a heating rate of $10{ }^{\circ} \mathrm{C} / \mathrm{min}$, until reaching $600^{\circ} \mathrm{C}$ (PARDAUIL et al., 2017).

\section{Fourier-transform infrared spectroscopy (FTIR) \\ The FTIR was used as an auxiliary} method to characterize the munguba oil. The infrared spectra were obtained with a Fourier-transform infrared spectrophotometer (Shimadzu Iraffinity-1 (Shimadzu)) using an attenuated total reflectance (ATR-IFTR) accessory, in a wavelength range of 4000 to $500 \mathrm{~cm}^{-1}, 4 \mathrm{~cm}^{-1}$ resolution and 32 scans. A zinc selenide crystal was used to perform this analysis (ROHMAN \& MAN, 2010).

Gas chromatography-mass spectrometry (CG-MS)

Prior to the analysis, the munguba oil was esterified according to MILINSK et al. (2011) with 
modifications, as follows: $50 \mu \mathrm{L}$ of the oil was mixed with $0.5 \mathrm{ml}$ of a $0.5 \mathrm{~mol} / \mathrm{L}$ potassium hydroxide methanolic solution and the mix was heated to $70{ }^{\circ} \mathrm{C}$ for $10 \mathrm{~min}$. After that, $400 \mu \mathrm{L}$ of a hydrochloric acid and methanol mix (1:4 v/v [volume/volume]) was added to the previous mixture, and the final solution was heated to $70{ }^{\circ} \mathrm{C}$ for 20 minutes. Finally, $1 \mathrm{~mL}$ of hexane was added to it and the mixture was vigorously stirred for 5 minutes. After the esterification, $100 \mu \mathrm{L}$ of the supernatant was collected and diluted with 900 $\mu \mathrm{L}$ of hexane.

The oil's fatty acid composition was determined in a gas chromatograph (Agilent Technologies 7890A) coupled to a mass spectrometer (Agilent Technologies 5975C), using helium as the carrier gas $(1.0 \mathrm{~mL} / \mathrm{min})$ in the following conditions: $1 \mu \mathrm{L}$ of sample injection volume; 3:1 split; column: HP5-MS; MS Source: $230{ }^{\circ} \mathrm{C}$; MS Quad: $150{ }^{\circ} \mathrm{C}$; gradient: $140{ }^{\circ} \mathrm{C}$ (2 minutes), $4{ }^{\circ} \mathrm{C} / \mathrm{min}$ until reaching $180{ }^{\circ} \mathrm{C}, 0.5{ }^{\circ} \mathrm{C} / \mathrm{min}$ until reaching $200{ }^{\circ} \mathrm{C}, 5{ }^{\circ} \mathrm{C} /$ min until reaching $250{ }^{\circ} \mathrm{C}$ (3 minutes); Full time: 70 minutes. The fatty acids were identified based on the standard retention time (Lipid Standards SigmaAldrich: FAMEs mixtures C14:0 - C22:0) injected under the same conditions.

\section{Total phenolic content determination}

The extraction of the phenolic compounds from the munguba oil was performed according to SCHONS et al. (2017), using $2 \mathrm{~g}$ of oil mixed with 5 $\mathrm{mL}$ of methanol $60 \%(\mathrm{v} / \mathrm{v})$ and $2 \mathrm{~mL}$ of hexane. This mix was stirred for 10 minutes, then left resting for 10 minutes, followed by 10 minutes of centrifugation at $3000 \mathrm{rpm}$, aiming to separate the oily phase from the hydroalcoholic phase, the latter was the portion containing the phenolic content of the sample.

The total phenolic content determination was performed following the Folin-Ciocalteu method with modifications (SCHONS et al., 2017). To build the calibration curve, gallic acid was used in concentrations ranging from 1 to $10 \mu \mathrm{g} / \mathrm{mL}$ and total phenolic content values were presented as gallic acid equivalent (microgram of gallic acid equivalents per gram of oil - $\mu \mathrm{gEAG} / \mathrm{g}$ ).

\section{RESULTS AND DISCUSSION}

\section{Oil physicochemical characterization}

The ultrasound-assisted extraction presented a $47.70 \%$ yield of a light yellow colored oil. JORGE \& LUZIA (2012), OLIVEIRA et al. (2019) and RODRIGUES et al. (2019) obtained yields of $38.39 \%, 40.4 \%$ and $43.42 \%$, respectively, using the Soxhlet extraction method. These yields are considered high, and variations found in the literature can be attributed to several different reasons, such as soil characteristics, weather changes, plant injury, and fruit ripening time, as well as method and solvent used in the oil extraction. Aiming to compare the yield of the ultrasound-assisted method, a Soxhlet extraction was performed using the same dried fruit sample for 2 hours, same time gap used in the ultrasoundassisted method, which provided a yield of $27.20 \%$, confirming the ultrasound method is more efficient.

The analyzed physicochemical parameters are shown in table 1.

The $\%$ of free fatty acids ( $\%$ FFA) can provide some information about the oil and indicate possible oxidation and deterioration, which can be used as preliminary data about its quality. The munguba oil presented an acid value of $2.06 \pm 0.04$ $\%$, a value inferior to those found by CAMARGO (2008) and SILVA (2011) using munguba oil extracted by the Soxhlet method $(4.31 \%$ and $2.97 \%$, respectively). The acidity of an oil can be influenced by its moisture, therefore, the absence of moisture in the oil may be one of the reasons for its low acid value. Furthermore, the mentioned acid values suggest that the munguba oil has naturally higher acid values.

The iodine value and the refractive index evaluation contribute to the determination of the oil's fatty acid unsaturation. Several authors who studied oils in general, observed that the higher the iodine value, higher is the refractive index and, usually, higher is the unsaturation level of the oil's fatty acids (LI et al., 2015; PAUCAR-MENACHO, 2015; GODSWILL et al., 2018).

The iodine value found for the munguba oil was $43.77 \pm 0.47 \mathrm{~g} \mathrm{I}_{2} / 100 \mathrm{~g}$ and the refractive index was $1.465\left(40{ }^{\circ} \mathrm{C}\right)$. The presented values suggest a smaller amount of unsaturated fatty acids, showing that most of the munguba oil's fatty acids are saturated. These results were confirmed by the fatty acid profile performed by GC-MS (Table 2). These results are consistent with those found by JORGE \& LUZIA (2012), who obtained iodine and refraction index values of $27.4 \mathrm{~g} \mathrm{I}_{2} / 100 \mathrm{~g}$ and 1.4569 $\left(40^{\circ} \mathrm{C}\right)$, respectively.

The peroxide value analysis aims to investigate the oxidative degradation of the oil, considering the maximum value established by the CODEX ALIMENTARIUS (2019), which is $10 \mathrm{meq} /$ $\mathrm{Kg}$. The value found for the munguba oil was $3.75 \pm$ $0.02 \mathrm{meq} / \mathrm{Kg}$, which shows that the oil was in good state of conservation. 
Table 1 - Physicochemical parameters of munguba oil extracted by the ultrasound-assisted method.

\begin{tabular}{lc}
\hline Physicochemical Parameters & Value \\
\hline \%FFA (oleic acid) & $2.06 \pm 0.04$ \\
Iodine value $\left(\mathrm{g} \mathrm{I}_{2} / 100 \mathrm{~g}\right)$ & $43.77 \pm 0.47$ \\
Refractive index $\left(40^{\circ} \mathrm{C}\right)$ & 1.465 \\
Peroxide value $(\mathrm{meq} / \mathrm{Kg})$ & $3.75 \pm 0.02$ \\
Saponification value $(\mathrm{mg} \mathrm{KOH} / \mathrm{g})$ & $181.70 \pm 2.78$ \\
Density $(\mathrm{g} / \mathrm{mL})$ & 0.9290 \\
Ash content $(\% \mathrm{~m} / \mathrm{m})$ & $1.84 \pm 0.00$ \\
Moisture $(\%)$ & ND $^{*}$ \\
\hline
\end{tabular}

${ }^{*} \mathrm{ND}=$ Not detected.

The saponification value analyzes the presence of high and low molecular weight fatty acids in the oil, hence, the higher the saponification value, the lower is the fatty acid's molecular weight (MORETTO \& FETT, 1998). The value for the munguba oil was $181.7 \pm 2.78 \mathrm{KOH} / \mathrm{g}$, which indicates the presence of low molecular weight fatty acids. SILVA (2011) and JORGE \& LUZIA (2012) found similar results, $172.0 \mathrm{mg} \mathrm{KOH} / \mathrm{g}$ and $208.0 \mathrm{mg}$ $\mathrm{KOH} / \mathrm{g}$ respectively, analyzing an oil extracted by the Soxhlet method. The saponification value presented by the munguba oil highlights its potential for use in the manufacture of edible products, since this result falls within the range established by the CODEX ALIMENTARIUS for crude vegetable oils (168 $265 \mathrm{mg} \mathrm{KOH} \mathrm{g}^{-1}$ ), comparable to mustard seed oil, palm oil, babassu oil and soybean oil.

Density and viscosity values reflect the degradation processes the oil goes through, since their increase is a result of polymerization reactions that cause the formation of higher molecular weight products within the oil. Such modifications in oil structure may, for instance, compromise the characteristics of cosmetic and pharmaceutical formulations containing this oil. Thus, density and viscosity values work as additional parameters in the evaluation of the oil's quality, as well as for the optimization of operational processes that involve, mainly, the material flowability.

Oil density is influenced by the amount of unsaturation of its fatty acids, hence polyunsaturated fatty acids have higher density values than saturated fatty acids (DENG et al., 2018). Munguba oil presented a relative density value of $0.9290 \mathrm{~g} / \mathrm{mL}$ at 25 ${ }^{\circ} \mathrm{C}$, a characteristic value for oils with high amounts of saturated fatty acids, information confirmed by the GC-MS analysis.

Viscosity measures the internal resistance of a fluid's flow. This property varies in vegetable oils, depending on the amount of unsaturated fatty acids, fatty acid chain length and its ramifications. Figure 1 shows the decline of munguba oil's dynamic viscosity

Table 2 - Fatty acid composition of the munguba oil extracted by the ultrasound-assisted method.

\begin{tabular}{lc}
\hline Fatty acid & Percentage in weight $^{*}$ \\
\hline Palmitic C16:0 & 75.27 \\
\hline Oleic C18:1 & 8.19 \\
\hline Linoleic C18:2 & 6.91 \\
\hline Stearic C18:0 & 4.37 \\
\hline Elaidic C18:1 & 1.13 \\
\hline Arachidic C20:0 & 0.27 \\
\hline Myristic C14:0 & 0.26 \\
\hline Behenic C22:0 & 0.01 \\
\hline
\end{tabular}

Ciência Rural, v.50, n.12, 2020. 


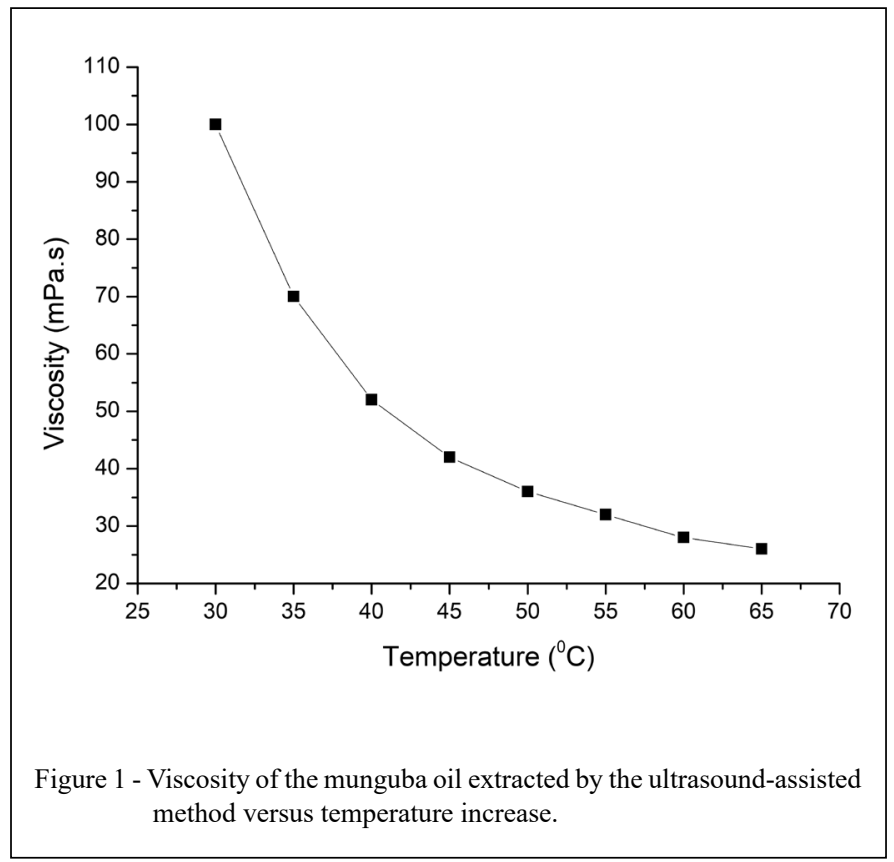

as temperature increases. The variation in viscosity values is higher under lower temperatures and it goes down as temperature goes up. This happens due to a decrease in the intermolecular forces, which leads to a separation of the fatty acid molecules, consequently causing a downturn in the viscosity values (DAVIES, 2016; SAJJADI et al., 2016).

\section{Thermogravimetric analysis (TG-DTG curves)}

The TG-DTG curves (Figure 2) provide moisture and ash content values. The oil presented an absence of moisture, which reinforces the quality of the extraction process, favoring the stability of the oil since it brings down the possibility of hydroelectrolytic oxidation, enzyme action and microbial growth. The ash content provides preliminary information about nutritional value, due to the presence of minerals, as well as identifying possible adulteration and presence of impurities. Results for ash content $(1.84 \pm 0.00 \%)$ in the munguba oil suggest small amounts of inorganic compounds and/or impurities. On that matter, RODRIGUES et al., (2019) found an ash content value of $4.160 \%$ in the munguba seed, showcasing high amounts of minerals, like potassium and zinc. TG-DTG curves also allowed investigation of the oil's thermal stability. The oil remained stable until $300{ }^{\circ} \mathrm{C}$ and from that point on, the mass decreased by $98.16 \%$, due to decomposition processes and/or oil oxidation.

\section{Differential scanning calorimetry (DSC)}

The DSC curve (Figure 3) presented both endothermic and exothermic events. The first endothermic peak occurred at $32.2{ }^{\circ} \mathrm{C}$ and refers to the melting point of the oil, corroborating the value of $32.0{ }^{\circ} \mathrm{C}$ provided by the test performed with the capillary tube (Cc 3-25). The enthalpy involved in this process was $-54.87 \mathrm{~J} / \mathrm{g}$. Endothermic and exothermic peaks presented over $300{ }^{\circ} \mathrm{C}$ are probably due to oil degradation, which matches the results observed on the TG-DTG curve. The DSC curve is an excellent tool used in the quality control of oils, since it is a fast analysis method, uses small amounts of sample, and can be used in its identification and purity evaluation.

\section{Fourier-transform infrared spectroscopy (FTIR)}

FTIR is commonly used in molecular structure identification, providing absorption bands directly related to functional groups, and allows monitoring of changes in the quality of a substance (BENDINI et al., 2007; ROHMAN \& MAN, 2010).

The main absorption bands presented in the infrared spectrum (Figure 4) show symmetrical and asymmetrical bond stretching at 2924 and 2854 $\mathrm{cm}^{-1}$, indicating a saturated carbon chain $(\mathrm{C}-\mathrm{H})$, and a prominent axial bond stretch band $(\mathrm{C}=\mathrm{O})$ at 1747 $\mathrm{cm}^{-1}$. Some more stretching bands can be found in the fingerprint region, which occurs between 1650 and $500 \mathrm{~cm}^{-1}$, however, some specific bands stand out, like 


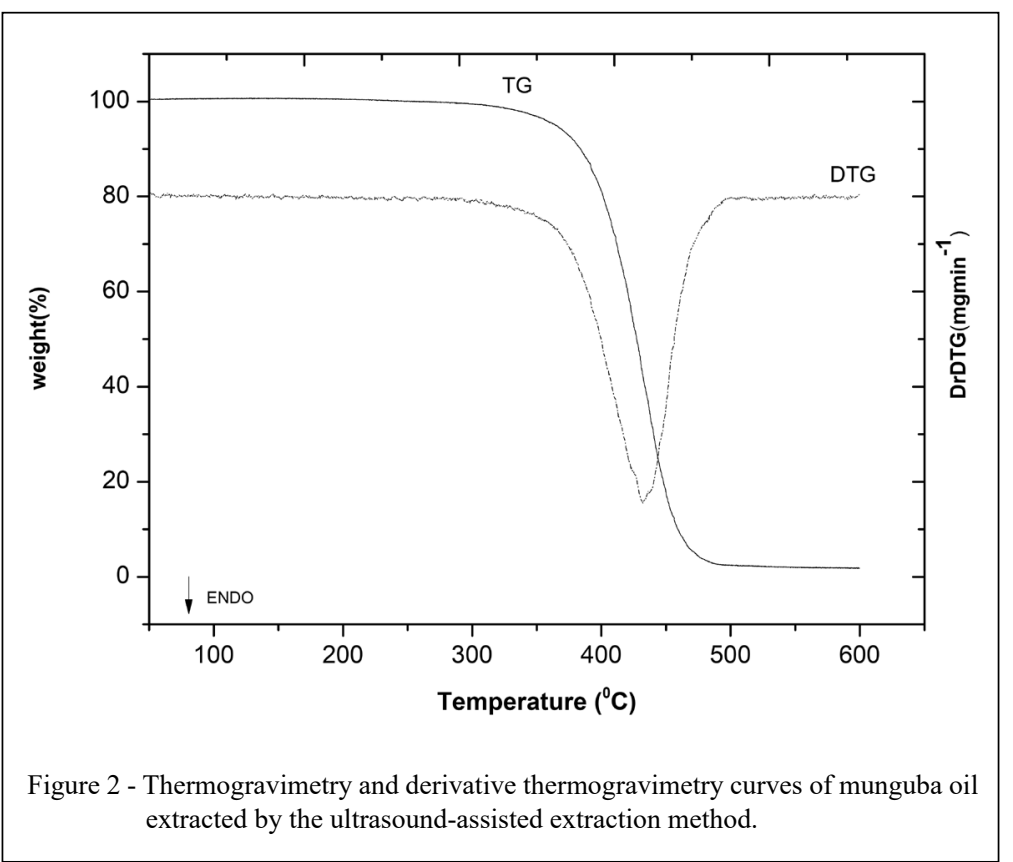

the one related to ester groups bond stretches (1149 and $1107 \mathrm{~cm}^{-1}$ ) and the one related to the rocking vibration from the $\mathrm{CH}_{2}$ bond $\left(722 \mathrm{~cm}^{-1}\right)$. Furthermore, it's worth noting that the exact band position and the detection intensity are directly dependent on the fatty acids' composition (SILVERSTEIN et al., 2005; SHI et al., 2017).
Gas chromatography-mass spectrometry (CG-MS)

GC-MS analysis shows that the fatty acids present in the munguba oil are mostly saturated (Table 2), confirming the results provided by the iodine value, refractive index, density and viscosity analysis.

The oil presented $80.18 \%$ of saturated fatty acids and $19.82 \%$ of unsaturated fatty acids.

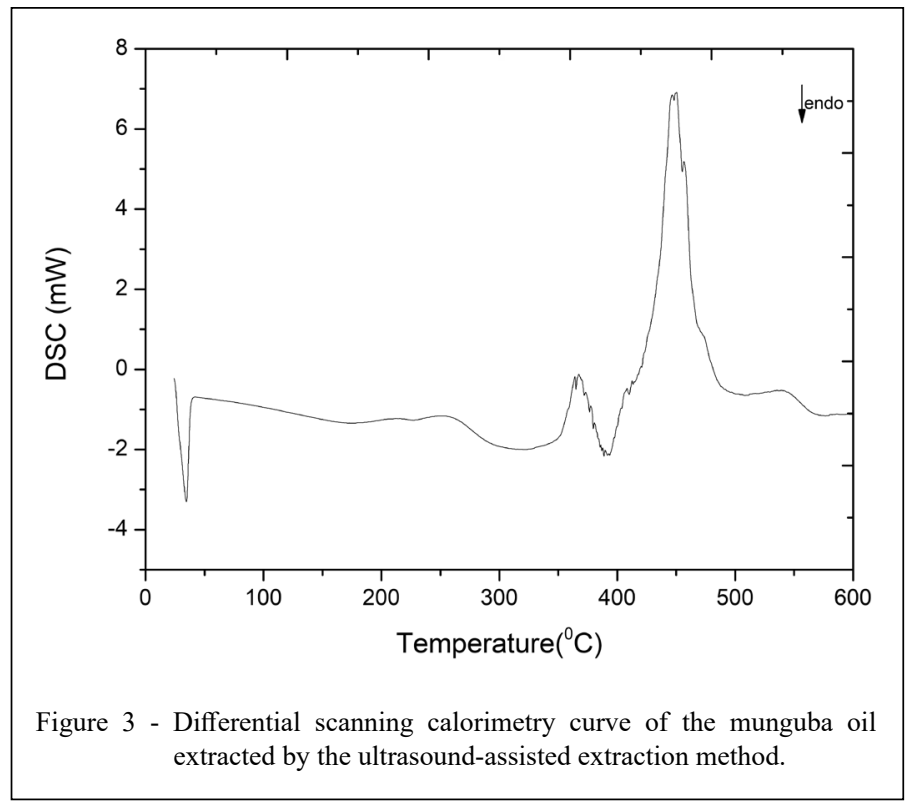

Ciência Rural, v.50, n.12, 2020. 


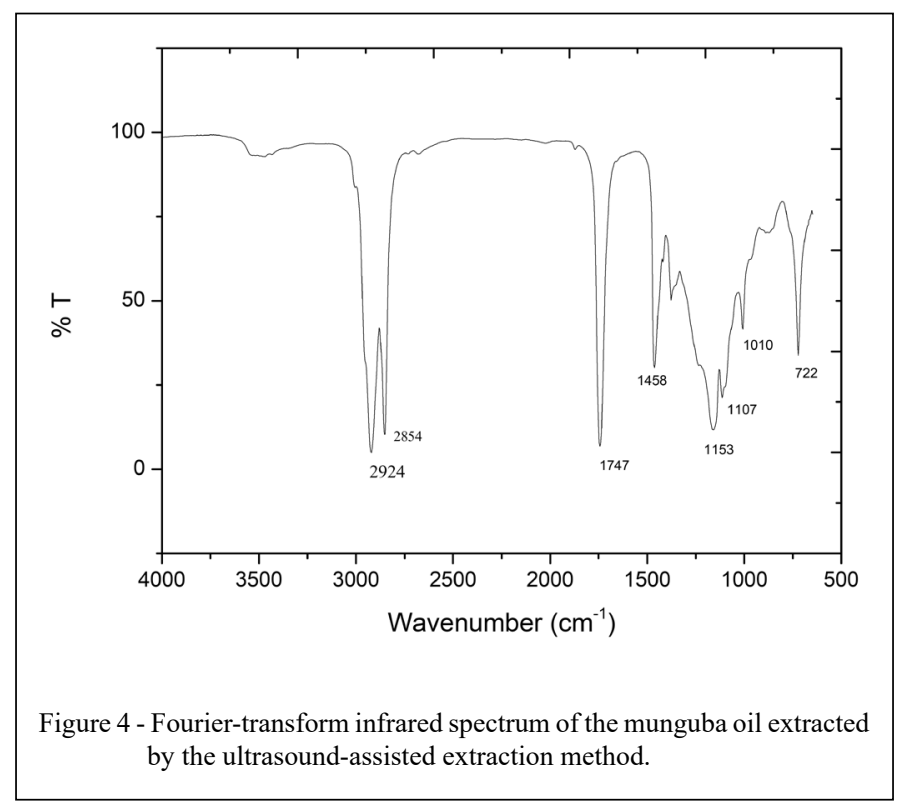

Palmitic acid was found at a higher percentage (75.27\%) amongst the saturated fatty acids, followed by oleic acid $(8.193 \%)$ and linoleic acid $(6.906 \%)$. Other authors who studied the munguba oil also found palmitic acid as its main fatty acid (SILVA, 2011; JORGE \& LUZIA, 2012; RODRIGUES et al., 2019; OLIVEIRA et al., 2019), and RODRIGUES et al. (2019), and OLIVEIRA et al. (2019) found fatty acid percentages similar to this study, using the Soxhlet oil extraction method. Variation in fatty acid amounts might be due to climate and soil specific characteristics, seasonal period and weather changes to which the plants were exposed, as well as the extraction method.

The presence of palmitic acid, the main fatty acid found in the oil, favors the use of the oil in pharmaceutical and cosmetic products. KIM et al. (2008) studied the stimulating effects of fatty acids in the diclofenac permeation on the skin and found that palmitic acid showed a major potential as an adjuvant. RAISER et al. (2018a), developed and evaluated the quality and stability of cosmetic formulations containing 3 and $5 \%$ of munguba oil and found that the spreadability of formulations was optimized with the increase of oil amounts in it.

\section{Total phenolic content determination}

The phenolic content determination was performed in order to check the natural antioxidant content of the oil, even if in small quantities, since phenolic compounds have a positive influence on human health.
Plus, the presence of these compounds helps to avoid lipid oxidation, reducing chances of oil deterioration, as well as of the products developed from it.

The Folin Ciocalteu method performed with the munguba oil presented as results, a line equation $(y=0.0098 x+0.0292)$, with a coefficient of determination $\mathrm{r}^{2}=0.9995$ and phenolic content of $55.02 \pm 1.87 \mu \mathrm{s} E A G / g$. RODRIGUES et al. (2019), evaluated the total phenolic content in the munguba seed and found a value of $775.17 \mu \mathrm{gEAG} / \mathrm{g}$ of dried matter. The results from the oil (55.02 $\pm 1.87 \mu \mathrm{gEAG} / \mathrm{g})$, when compared with the results from the munguba seed, suggest that the oil is responsible for about $7 \%$ of the total phenolic compounds in the seed, which can contribute to biological and nutritional use.

\section{CONCLUSION}

The results from this study show that the ultrasound-assisted extraction method provided efficiency to the extraction process and satisfactory yielding, making it a suitable alternative to the traditional methods, since it is an easy method to perform, which uses low amounts of solvent, is quick, efficient and low cost. Furthermore, the provided oil presented good quality characteristics, thermal stability and contained important fatty acids and an interesting amount of phenolic compounds, making it a suitable and sustainable option for use as an adjuvant in the manufacturing of food products, cosmetics, pharmaceuticals and biofuels. 


\section{ACKNOWLEDGEMENTS}

The authors acknowledge the financial support from Coordenação de Aperfeiçoamento de Pessoal de Nível Superior (CAPES) scholarship, Brasil - Finance code 001.

\section{DECLARATION OF CONFLICT OF INTERESTS}

The authors declare no conflict of interest. The founding sponsors had no role in the design of the study; in the collection, analyses, or interpretation of data; in the writing of the manuscript, and in the decision to publish the results.

\section{AUTHORS' CONTRIBUTIONS}

All authors contributed equally for the conception and writing of the manuscript. All authors critically revised the manuscript and approved of the final version.

\section{REFERENCES}

AMERICAN OIL CHEMISTS SOCIETY - AOCS - Official Methods and Recommended Practices of the American Oil Chemists Society. Washington, 2004.

BENDINI, A.; et al., Preliminary evaluation of the application of the FTIR spectroscopy to control the geographic origin and quality of virgin olive oils. Journal of Food Quality, v.30, p.424-437, 2007. Available from: <https://onlinelibrary.wiley.com/doi/full/1 0.1111/j.1745-4557.2007.00132.x>. Accessed: Nov. 5, 2019. doi: 10.1111/j.1745-4557.2007.00132.x

CAMARGO, M. F. Caracterização química do óleo extraído da Pachira aquatica Aubl. Periódico Tchê Química, v.5, 1922, 2008. Available from: <https://www.researchgate.net/ publication/49601859 CARACTERIZACAO QUIMICA DO OLEO_EXTRAIDO_DA_Pachira_aquatica_Aubl $>$. Accessed: Apr. 28, 2018.

CODEX ALIMETARIUS. Available from: $<$ https://mvo.nl/media/voedselveiligheid/codex_standard_named_ vegetable_oils.pdf $>$. Accessed: Nov. 18, 2019.

DAVIES, R. M. Effect of the temperature on dynamic viscosity, density and flow rate of some vegetable oils. Journal of Scientific Research in Engineering \& Technology, v.1, p.1424, 2016. Available from: <https://www.researchgate.net/ publication/317336251_EFFECT_OF_THE_TEMPERATURE ON_DYNAMIC_VISCOSITY_DENSITY_AND_FLOW RATEOF_SOME_VEGETABLE_OILS>. Accessed: Nov. 5, 2019.

DENG, J.; et al., Comparative study on composition, physicochemical and antioxidant characteristics of different varieties of kiwifruit seed oil in China. Food Chemistry, v.264, p.411-418, 2018. Available from: <https://pubmed.ncbi.nlm. nih.gov/29853395/>. Accessed: Nov. 9, 2019. doi: 10.1016/j. foodchem.2018.05.063.

DOURADO, D.; et al., Development and evaluation of emulsifying systems of the material grease from Brazilian flora. Journal of Pharmacognosy Research, v.3, p.130-140, 2015. Available from: <https://www.researchgate.net/publication/302191946
Development_and_evaluation_of_emulsifying_systems_of_the material grease from Brazilian flora $>$. Accessed: Jul. 19, 2019.

GODSWILL, A. G.; Effects of repeated deep frying on refractive index and peroxide value of selected vegetable oils. International Journal of Advanced Academic Research $\mid$ Sciences, Technology \& Engineering, v.4, p.106-119, 2018. Available from: <https:// www.researchgate.net/publication/325066839_EFFECTS_OF_ REPEATED DEEP FRYING ON REFRACTIVE INDEX AND_PEROXIDE_VALUE_OF_SELECTED_VEGETABLE_ OILS $>$. Accessed: Oct. 17, 2019 .

HELENO, S. A.; et al., Optimizations of ultrasound-assisted extraction to obtain mycosterols from Agaricus bisporus L. by response surface methodology and comparison with conventional Soxhlet extraction. Food Chemistry, v.197, p.1054-1063, 2016. Available from: <https://pubmed.ncbi.nlm.nih.gov/26675841/>. Accessed: Jul. 17, 2019. doi: 10.1016/j.foodchem.2015.11.108.

HERNÁNDEZ-SANTOS, B.; et al., Effect of oil extraction assisted by ultrasound on the physicochemical propierties and fatty acid profile of pumpkin seed oil (Cucurbita pepo). Ultrasonics Sonochemistry, v.31, p.429-436, 2016. Available from: <https://www.sciencedirect. com/science/article/abs/pii/S1350417716300281?via\%3Dihub>. Accessed: Jul. 17, 2019. doi: 10.1016/j.ultsonch.2016.01.029.

JORGE, N.; LUZIA, D. M. M. Characterization of seed oil Pachira aquatica Aublet for food utilization. Acta Amazônica, v.42, p.149-156, 2012. Available from: <https://www.scielo.br/ scielo.php?script $=$ sci_arttext\&pid=S0044-9672012000100017 $>$. Accessed: Jul. 17, 2019. doi: 10.1590/S0044-59672012000100017.

KIM, M. J.; et al., Skin Permeation Enhancement of Diclofenac by Fatty Acids. Drug Delivery, v.15, p.373-379, 2008. Available from: < https://pubmed.ncbi.nlm.nih.gov/18686081/>. Accessed: Jul. 15, 2019. doi: 10.1080/10717540802006898.

LI, H.; et al., Optimization of ultrasound-assisted hexane extraction of perilla oil using response surface methodology. Industrial Crops and Products, v.76, p.18-24, 2015. Available from: $\quad<$ https://www.sciencedirect.com/science/article/abs/pii/ S0926669015301898?via\%3Dihub>. Accessed: Nov. 16, 2019. doi: 10.1016/j.indcrop.2015.06.021.

LORENÇON, J. R.; ANDRADE, S. C.; ANDRADE, D. J. Mites occurrence on Pachira aquatica Aubl. including aspects of external mouthpart morphology of Brachytydeus formosa (Acari: Tydeidae). Brazilian Journal of Biology, v.76, p.136-143, 2016. Available from: <https://www.scielo.br/scielo.php?pid=S151969842016000100136\&script=sci_arttext\&tlng=en $>$. Accessed: Jun. 13, 2019. doi: 10.1590/1519-6984.15114.

MARAN, J. P.; et al., Ultrassound assisted extraction of bioactive compounds from Nephelium lappaceum L. fruit peel using central composite face centered response surface design. Arabian Journal of Chemistry, v.10, S1145-S1157, 2017. Available from: <https:// www.sciencedirect.com/science/article/pii/S1878535213000397>. Accessed: Nov. 15, 2019. doi: 10.1016/j.arabjc.2013.02.007.

MILINSK, M. C.; et al., Influence of the esterification method on the quantification of olive oil fatty acids. Semina: Ciências Exatas e Tecnológicas, v.32, p.139-150, 2011. Available from: <http://www. uel.br/revistas/uel/index.php/semexatas/article/view/8349/0>. Accessed: Jun. 13, 2019. doi: 10.5433/1679-0375.2011v32n2p139. MORETTO E.; FETT R. Tecnologia de Óleos e Gorduras Vegetais na Indústria de Alimentos. Varela. São Paulo, 1998. 
OLIVEIRA, L. P.; et al., Biofuel production from Pachira aquatica Aubl and Magonia pubescens A St-Hil: Physical-chemical properties of neat vegetable oils, methyl-esters and bio-oils (hydrocarbons). Industrial Crops \& Products, v.127, p.158-163, 2019. Available from: <https://www.sciencedirect.com/science/ article/abs/pii/S0926669018309348?via\%3Dihub>. Accessed: Jul. 17, 2019. doi: 10.1016/j.indcrop.2018.10.061.

PARDAUIL, J. J. R.; et al., Characterization, thermal properties and phase transitions of amazonian vegetable oils. Journal of Thermal Analysis and Calorimetry, v.127, p.1221-1229, 2017. Available from: <https://link.springer.com/article/10.1007/ s10973-016-5605-5>. Accessed: Jul. 17, 2019. doi: 10.1007/ s10973-016-5605-5.

PAUCAR-MENACHO, L. M.; et al., Comparative study of physical-chemical features of sacha inchi oil (Plukenetia volubilis L.), olive oil (Olea europaea) and fish oil. Scientia Agropecuaria, v.6, p.279-290, 2015. Available from: <http://www.scielo.org. pe/scielo.php?pid=S2077-99172015000400005\&script $=$ sci abstract\&tlng $=$ en $>$. Accessed: Nov. 13, 2019. doi: 10.17268/sci. agropecu.2015.04.05.

PEREIRA, M. G.; et al., Assessment of subcritical propane, ultrasound-assisted and Soxhlet extraction of oil from sweet passion fruit (Passiflora alata Curtis) seeds. The Journal of Supercritical Fluids, v.128, p.338-348, 2017. Available from: <https://www.sciencedirect.com/science/article/abs/pii/ S089684461730044X?via\%3Dihub>. Accessed: Oct. 10, 2019. doi: 10.1016/j.supflu.2017.03.021.

PERRIER, A.; et al., Effect of ultrasound and green solvents addition on the oil extraction efficiency from rapessed flakes. Ultrassonics Sonochemistry, v.39, p.58-65, 2017. Available from: <https://www.sciencedirect.com/science/article/abs/pii/ S1350417717301608?via\%3Dihub>. Accessed: Oct. 10, 2019. doi: 10.1016/j.ultsonch.2017.04.003.

RAISER, A. L.; et al., Stability and potential antioxidant activity essay of pequi oil (Caryocar brasiliense Camb.) in Cosmetic Emulsions. Latin American Journal of Pharmacy, v.37, p.144 151, 2018. Available from: <http://www.latamjpharm.org/search. php>. Accessed: Feb. 10, 2018.

RAISER, A. L.; et al., Evaluation of stability and potential antioxidante activity of munguba (Pachira aquatica Aublet) oil in cosmetic emulsions. Latin Americam Journal of Pharmacy, v.37, p.1491-1497, 2018. Available from: <http://www.latamjpharm.org/ search.php $>$. Accessed: Apr. 1, 2018.

RODRIGUES, A. P.; et al., Chemical Composition and Antioxidant Activity of Monguba (Pachira aquatica) Seeds.
Food Research International, v.121, p.880-887, 2019. Available from: $\quad<$ https://www.sciencedirect.com/science/article/abs/pii/ S0963996919300146?via\%3Dihub>. Accessed: Dec. 18, 2019. doi: 10.1016/j.foodres.2019.01.014.

ROHMAN, A.; CHE MAN, Y. B. Fourier transform infrared (FTIR) spectroscopy for analysis of extra virgin olive oil adulterated with palm oil. Food Research International, v.43, p.886-892, 2010. Available from: $<$ https://www.sciencedirect.com/science/article/abs/pii/ S096399690900369X?via\%3Dihub>. Accessed: Nov. 15, 2019. doi: 10.1016/j.foodres.2009.12.006.

SAJJADI, B.; RAMAN, A. A. A.; ARANDIYAN, H., A comprehensive review on properties of edible and non-edible vegetable oil-based biodiesel: Composition, specifications and prediction models. Renewable and Sustainable Energy Reviews, v.63, p.62-92, 2016. Available from: $<$ https://www.sciencedirect.com/science/article/abs/pii/ S1364032116301459?via\%3Dihub>. Accessed: Dec. 15, 2019. doi: 10.1016/j.rser.2016.05.035.

SCHONS, J. I.; et al., Extração assistida por ultrassom e caracterização do óleo da castanha-do-brasil (Bertholletia excelsa H.B.K.). Interciencia, v.42, p.586-590, 2017. Available from: $<$ https://www.interciencia.net/wp-content/ uploads/2017/10/05-586-42-9.pdf>. Accessed: Feb. 1, 2018.

SHI, L.; et al., Analysis of edible vegetable oils by infrared absorption spectrometry. Advances in Engineering Research, v.86 (2017), p.286-289, 2017. Available from: <https://www. atlantis-press.com/proceedings/eame-17/25875810>. Accessed: Dec. 15, 2019. doi: 10.2991/eame-17.2017.67.

SILVA, B. L. A. Análise físico-química lipídica e morfologia das amêndoas das sementes da munguba (Pachira aquatica Aubl.). Revista UNI, 63-74, 2011.

SILVA, B. L. A.; AZEVEDO, C. C.; AZEVEDO, F. L. A. A. Propriedades Funcionais das proteínas de amêndoas da munguba (Pachira aquatica Aubl.). Revista Brasileira de Fruticultura, v.37, p.193-200, 2015. Available from: <https://www.scielo.br/scielo. php?script $=$ sci_abstract\&pid $=$ S0100-29452015000100193\&lng=e n\&nrm=iso\&tlng=pt $>$. Accessed: Feb. 9, 2018. doi: 10.1590/01002945-065/14.

SILVERSTEIN, R. M.; WEBSTER, F.; KIEMLE, D. J. Identification of organic compounds, seventh ed., John Wiley \& Sons, New York, 2005.

THE PLANT LIST. Available from: <http://www.theplantlist.org/ tpl1.1/record/kew-2412843>. Accessed: Jul. 10, 2019. 